Buana Sains Vol 8 No 2: 189-202, 2008

\title{
PENGARUH PEMANGKASAN TANAMAN SENGON TERHADAP KERAGAAN TANAMAN SELA DALAM SISTEM AGROFORESTRI SENGON
}

\author{
Abdul Hamid \\ Dinas Kehutanan Propinsi Jawa Timur
}

\begin{abstract}
The effects of pruning of Paraserianthes falcataria tree in an agroforestry system on yield of intercrops and tree performance were studied at Perhutani RPH Jatirejo, BKPH Pare, KPJH Kediri. Maize, stick nut, and chili were used as companion crops in between rows of two years old Paraserianthes falcataria tree. A split plot design with four replicates was set up for the experiment. The trees were $25 \%, 50 \%$ and $75 \%$ pruned. The measured parameters included growth and yield of the intercrops and performance of the tree. Results of this study showed that regular pruning of the agroforestry tree and planting of intercrops did not hinder growth and performance of the agroforestry tree, especially that was pruned $75 \%$. Pruning of the tree also increase yield of the intercrops.
\end{abstract}

Key words: pruning, agroforestry, intercrops

\section{Pendahuluan}

Salah satu alternatif untuk meningkatkan pendapatan petani sekitar hutan adalah peningkatan produktivitas lahan dan tenaga kerja yang mereka miliki. Upaya tersebut dapat dilakukan dengan cara antara lain meningkatkan produktivitas per satuan luas dan waktu dengan jalan meningkatkan intensitas penanaman dan penganekaragaman jenis tanaman.

Upaya peningkatan produksi per satuan luas dan waktu memakai cara penambahan intensitas penanaman dan penganekaraman jenis tanaman, pada hakekatnya merupakan sistem atau bentuk pola pertanaman ganda. Bentuk pola usahatani campuran tersebut dalam istilah kehutanan dikenal sebagai bentuk agroforestri. Keberhasilan sistem agroforestri terletak pada eksploitasi terhadap interaksi-interaksi antara komponen-komponen sistem agroforestri (Nair, 1993). Pohon dapat menimbulkan efek positif terhadap ketersediaan air tanah bagi tanaman sela yang tumbuh di antara pohon. Selain itu, naungan cenderung memberikan efek penyangga (buffer) terhadap fluktuasi suhu dan terjadinya suhu ekstrem, baik suhu tanah maupun suhu udara di atas permukaan tanah.

Pohon sengon (Paraseriatthes falcataria) merupakan salah satu tanaman pokok hutan yang banyak digunakan dalam sistem agroforestri sebagai salah satu bentuk pola usahatani terpadu di wilayah KPH Kediri, Jawa Timur. Dalam sistem agroforestri sengon tersebut, petani seringkali melakukan diversifikasi jenis komoditas tanaman sela yang sesuai di antara tanaman sengon hingga umur tertentu. Jenis 
tanaman sela yang dibudidayakan umumnya nenas, jagung, kacang tunggak, dan cabe rawit.

Walaupun secara teknis sistem agroforestri sengon banyak memberikan pengaruh positif terhadap produktivitas lahan hutan, kerusakan hutan masih belum sepenuhnya dapat dikendalikan. Hal ini diduga berkaitan dengan terbatasnya masa kontrak petani untuk memanfaatkan lahan hutan dengan sistem agroforestri tersebut. Berdasarkan ketentuan Perum Perhutani, petani pengelola lahan hutan dengan sistem agroforestri (disebut petani pesanggem), hanya diperkenankan melakukan usahatani tanaman pangan (sebagai tanaman sela) selama 15-24 bulan, dengan asumsi bahwa penanaman tanaman sela di antara tanaman sengon yang berumur lebih dari 15 bulan (atau 24 bulan) akan menyebabkan terganggunya pertumbuhan tanaman sengon. Selain daripada itu, penaungan oleh tanaman sengon terhadap tanaman sela juga akan menurunkan produkvitas tanaman sela itu sendiri.

Akibat dari ketentuan tersebut di atas, setelah 15-24 bulan, petani harus memulai lagi usahatani sistem agroforestri tersebut di tempat lain. Untuk ini Perum Perhutani harus selalu menyediakan lahan untuk pola tersebut. Jika lahan baru tidak tersedia maka petani akan kehilangan pendapatan dari usahatani tanaman sela, dan sebagai akibatnya kerusakan hutan semakin sulit dihindarkan.

Rangkaian permasalahan tersebut di atas saat ini menjadi semakin rumit dan sulit dipecahkan. Jumlah penduduk yang bermukim di sekitar hutan semakin bertambah, sementara lahan hutan yang dapat disediakan Perum Perhutani untuk pengembangan sistem agroforestri semakin terbatas.
Salah satu alternatif yang dapat dilakukan adalah memperpanjang masa kontrak petani dalam pengelolaan lahan sistem agroforestri menjadi lebih panjang dari 24 bulan. Masalahnya, tanaman sengon yang berumur 2 tahun atau lebih telah cukup membentuk kanopi yang dapat menaungi tanaman sela di bawahnya yang dapat mempengaruhi pertumbuhan dan produksi tanaman sela. Untuk memperkecil pengaruh naungan tanaman sengon terhadap tanaman sela, tanaman sengon dapat dipangkas secara periodik. Bahan pangkasan dapat digunakan sebagai sumber bahan organik untuk memperbaiki / mempertankan produkstivitas tanah.

Namun demikian, hal ini masih sulit untuk diterapkan karena masih belum tersedia informasi yang akurat tentang (a) sampai berapa jauh tanaman sela dalam sistem agroforestri sengon dapat mempertahankan dan atau meningkatkan pertumbuhan dan kualitas lahan?, (b) sampai berapa jauh pola agroforestri sengon berpengaruh terhadap pertumbuhan dan hasil tanaman sela?, (c) apakah pemangkasan tanaman sengon untuk mengurangi naungan terhadap tanaman sela mempengaruhi pertumbuhan dan produksi tanaman sengon itu sendiri?

Makalah ini melaporkan hasil penelitian tentang pengaruh pemangkasan tanaman sengon umur 2 tahun (batas waktu sistem agroforestri sengon) dan pemupukan tanaman sela terhadap pertumbuhan dan hasil tanaman sela dan tanaman sengon.

\section{Bahan dan Metode}

Penelitian dilakukan di kawasan Perhutani RPH Jatirejo, BKPH Pare, KPJH Kediri pada bulan Juni 2000 sampai dengan Desember 2001. 
Pemilihan lokasi penelitian didasarkan pada pertimbangan bahwa RPH Jatirejo, BKPH Pare, KPH Kediri merupakan sentra pengembangan sistem agrorestri berbasis sengon di wilayah Perum Perhutani Unit II Jawa Timur namun demikian sasaran hutan kemasyarakatan masih belum sepenuhnya dapat dicapai.

Jenis tanah Regosol (Psamment) curah hujan $2000 \mathrm{~mm}$ tahun-1, temperatur rata- rata $26.65^{\circ} \mathrm{C}$, dengan rata-rata temperatur maksimum $31.55^{\circ} \mathrm{C}$ dan rata-rata temperatur minimum $23.55{ }^{\circ} \mathrm{C}$ serta kelembaban rata-rata $52 \%$. Percobaan dilakukan dengan menggunakan tanaman jagung, kacang tunggak dan cabe rawit sebagai tanaman sela dalam pola agroforestri sengon umur dua tahun di BKPH Pare, KPH
Kediri pada petak 4A. Pemilihan lokasi penelitian didasarkan hasil penelitian tahap I yang menunjukkan bahwa kandungan bahan organik tanah pada petak 4A yang digunakan untuk agroiforestri sengon daur 3 umur 2 tahun (D3U2) adalah paling rendah dibandingkan dengan lokasi lainnya. Tanaman kacang tunggak yang digunakan dalam penelitian adalah kacang tunggak varietas biji hitam, tanaman jagung varietas, dan tanaman cabe rawit varietas lokal. Perlakuan yang diuji cbakan meliputi jenis tanaman sela sebagai perlakuan utama, pemangkasan tanaman sengon sebagai sub perlakuan, dan pemupukan tanaman sela sebagai sub-sub perlakuan (Tabel 1).

Tabel 1. Perlakuan pemangkasan tanaman sengon dan pemupukan tanaman sela pada sistem agroforestri sengon daur tiga umur 2 tahun

\begin{tabular}{cl}
\hline Kode & Perlakuan \\
& Perlakuan utama (main treatment): Jenis Tanaman Sela \\
\hline JG & Jagung varietas BISI \\
CB & Cabe rawit varietas lokal \\
KT & Kacang tunggak varietas lokal biji hitam \\
& Sub perlakuan (sub-treatment): Pemangkasan Tanaman Sengon \\
PS-100 & Tanpa sengon (kontrol) \\
PS-75 & Sengon dipangkas $75 \%$ \\
PS-50 & Sengon dipangkas 50\% \\
PS-25 & Sengon dipangkas 25\% \\
& Sub-sub perlakuan (sub-sub treatment). Pemupukan Tanaman Sela \\
P0 & Tanpa peupuk (kontrol) \\
P1 & 135 kg N /ha dalam bentuk urea, $36 \mathrm{~kg}$ P205 ha -1 dalam bentuk SP 36, dan $25 \mathrm{~kg}$ \\
& K2O ha -1 dalam bentuk KCl \\
P2 & Pupuk kandang kambing $8.621 \mathrm{~kg} / \mathrm{ha}$ \\
P3 & Campuran pupuk kandang, pupuk P dan pupuk K dengan dosis $4.655 \mathrm{~kg}$ pupuk \\
& kandang ha -1 + 16 kg P205 ha -1 + 12.5 kg K2O / ha \\
\hline
\end{tabular}

Percobaan disusun dalam Rancangan Petak Terbagi dengan 4 ulangan. Ukuran tiap petak percobaan adalah 3 $\mathrm{m} \times 5 \mathrm{~m}$ yang di dalamnya terdapat dua baris tanaman sengon yang setiap baris terdiri atas lima tanaman sengon. Sebelum pelaksanaan percobaan, lahan di bawah tegakan sengon sejajar barisan dibersihkan, digemburkan dengan cangkul dan diratakan. Kemudian dibuat petak percobaan sebanyak 144 petak dengan ukuran masing-masing petak $3 \times 5 \mathrm{~m}$. Pemangkasan tanaman sengon diperkirakan dari jumlah cabang 
yang dipangkas dari bawah, yaitu: (a) pangkasan $25 \%$ berarti ada 2-3 cabang yang dilepas, (b) pangkasan $50 \%$ berarti ada 4-5 cabang yang dilepas, dan (c) pangkasan $75 \%$ berarti ada 6-7 cabang yang dilepaskan.

Pada masing-masing intensitas pemangkasan kemudian diukur intensitas cahaya yang masuk sesuai dengan persentase pemangkasan sebagai data pembanding. Pemupukan Urea dilakukan dua kali, yaitu pada saat tanam sebanyak $50 \%$ dosis dan sisanya diberikan dua minggu setelah tanam. Pupuk SP-36 dan KCl, serta pupuk kandang seluruhnya diberikan pada saat tanam Parameter tanaman sela terdiri dari: Pertumbuhan dan produksi tanaman sela (Luas Daun, Tinggi tanaman, Berat kering tanaman Jumlah daun, bunga, dan buah). Keragaan tanaman sengon (Tinggi tanaman sengon), Diameter, yaitu dengan mengukur rata-rata pohon sejajar setinggi dada orang dewasa (sekitar 1 $\mathrm{m})$. Volume kayu diukur dengan rumus: (1 / 4. $\pi$. $\mathrm{d} 2 \mathrm{x}$ tinggi $\mathrm{x}$ faftor koreksi $\mathrm{x}$ populasi per hectare).

\section{Hasil dan Pembahasan}

Keragaan Tanaman Sengon

Pemangkasan tanaman sengon dan penanaman tanaman sela di antara tanaman sengon ternyata tidak menghambat pertumbuhan tanaman sengon, justru memacu pertumbuhan tanaman sengon. Pemangkasan sengon $75 \%$ menghasilkan pertambahan tinggi, diameter dan volume kayu lebih besar dibandingkan dengan pemangkasan $50 \%$, dan 25\%. Namun demikian perbaikan keragaan akibat pemangkasan $25 \%$ dan $50 \%$ tidak berbeda nyata. Pengaruh positif sangat nyata dijumpai pada perlakuan pemangkasan sengon $75 \%$ (Tabel 2). Hasil pangkasan yang berupa daun dan berbagai jenis jaringan berkayu dalam sistem agroforestri disamping bermanfaat untuk memperkaya nitrogen juga memperbesar intensitas cahaya sehingga aktivitas mikroorganisme meningkat, dekomposisis lebih cepat dan kesuburan tanah akan lebih baik.

Tabel 2. Pengaruh Pemangkasan Tanaman Sengon terhadap Keragaan Tanaman Sengon

\begin{tabular}{cccccccccc}
\hline \multirow{2}{*}{$\begin{array}{c}\text { Pengamatan } \\
\text { Perlakuan }\end{array}$} & \multicolumn{3}{c}{ Tinggi $(\mathrm{m})$} & \multicolumn{3}{c}{ Diameter $(\mathrm{cm})$} & \multicolumn{3}{c}{ Volume (m3 h /ha) } \\
\cline { 2 - 10 } & Awal & $\begin{array}{c}\text { Akhir } \\
\text { Tambah } \\
\text { an }\end{array}$ & Awal & $\begin{array}{c}\text { Akhir } \\
\text { Tambah } \\
\text { an }\end{array}$ & Awal & Akhir & $\begin{array}{c}\text { Tambah } \\
\text { an }\end{array}$ \\
\hline PS0 & 7.57 & 8.47 & 0.9 & 9.4 & 9.8 & 0.4 & 19.02 & 21.26 & 2.24 \\
PS25 & 8.1 & 9.29 & 1.19 & 9.3 & 9.7 & 0.4 & 20.33 & 23.31 & 2.98 \\
PS50 & 7.42 & 8.63 & 1.21 & 9.4 & 10 & 0.4 & 18.64 & 21.65 & 3.01 \\
PS75 & 7.56 & 9.05 & 1.49 & 9 & 9.82 & 0.82 & 19.99 & 22.71 & 3.72 \\
\hline
\end{tabular}

Young (1989) menyatakan bahwa semakin tinggi intensitas pangkas yang dilakukan pada tanaman Paraserianthes falcataria, Gliricidia sepium, dan Flemingia macrophylla dengan rasio $\mathrm{C} / \mathrm{N}$ masingmasing 12:1, 12:1, dan 21:1 maka aktivitas mikroorganisme semakin meningkat yang ditandai dengan peningkatan percepatan dekomposisi 1.5 kali lebih cepat.

Biomassa dari daun-daun segar dari berbagai jenis perennial berkayu legume seperti Paraserianthes falcataria, Gliricidia sepium, dan Erythrina spp, mengalami dekomposisi yang relatif cepat dan melepaskan sebagian besar kandungan 
haranya (terutama nitrogen) dalam periode sekitar empat minggu setelah aplikasinya sebagai mulsa permukaan pada kondisi iklim tropika basah (Young, 1989). Dalam situasi dimana pelepasan nitrogen yang cepat sangat diperlukan, material mulsa seperti ini sangat bagus.

\section{Pertumbuban dan Hasil Tanaman Sela}

\section{Tinggi Tanaman Sela}

Pemangkasan tanaman sengon berpengaruh nyata terhadap tinggi tanaman sela cabai, jagung dan kacang tunggak. Semakin banyak bagian tanaman sengon yang dipangkas maka pertumbuhan tanaman sela cabai, jagung, dan kacang tunggak semakin baik.

Tanaman sela tertinggi diperoleh pada perlakuan PS100P3 (cabai), PS50P3 (jagung), dan PS73P3 (kacang tunggak), sedangkan yang terendah diperoleh pada perlakuan PS25P0 untuk semua tanaman sela (Gambar 1). Di antara ketiga tanaman sela yang ditanam di bawah tegakan sengon ternyata tanaman jagung sangat nyata dipengaruhi oleh intensitas pemangkasan. Jagung yang ditanam tanpa pupuk dengan intensitas pangkas hanya 25\% memperoleh tinggi tanaman hanya $98 \mathrm{~cm}$. Apabila ditanam di bawah tanaman sengon yang dipangkas $75 \%$ (P75) atau ditanam secara monokultur (P100), tanaman menjadi lebih tinggi, yaitu 123.4 dan $164 \mathrm{~cm}$ dan berbeda sangat nyata pada Uji Duncan taraf 1\%.

Pertumbuhan tanaman cabai dan kacang tunggak tidak dipengaruhi oleh pemangkasan tetapi dipengaruhi oleh pemupukan. Tinggi tanaman cabai yang ditanam secara monokultur (P100) pada perlakuan P0 dan P3 adalah 87.9 dan $100.64 \mathrm{~cm}$.
Kacang tunggak yang ditanam di bawah tanaman sengon yang dipangkas $75 \%$ (PS 75), memperoleh tinggi tanaman $84.9 \mathrm{~cm}$ jika tidak dipupuk (P0) dan $100.3 \mathrm{~cm}$ jika dipupuk (P3). Secara umum dapat dikatakan bahwa pertumbuhan tanaman jagung sangat dipengaruhi oleh besarnya intensitas cahaya matahari yang masuk bahkan kenyataan di lapangan ada jagung yang tidak tumbuh akibat kekurangan cahaya.

Menurut Cannell (1983), intensitas kompetisi cahaya dapat diperingan atau diperparah oleh kondisi kekurangan hara, tergantung pada toleransi tanaman terhadap kekurangan hara. Toleransi tanaman terhadap naungan tergantung pada jalur-fotosintetiknya dan hasil yang dipanen. Tanaman penghasil buah dan biji, termasuk tanaman cabai dan jagung, lebih tidak toleran terhadap naungan dibandingkan dengan tanaman kacang tunggak. Oleh karena itu kacang tunggak lebih baik pertumbuhannya dibawah tegakan sengon sehingga berat kering tanaman pun lebih tinggi dibandingkan kedua jenis tanaman lainnya.

Kompetisi hara dapat mereduksi pertumbuhan dan hasil tanaman, terutama komponen tanaman sela semusim dalam sistem agroforestri. Para ahli berpendapat bahwa terbatasnya sistem perakaran tanaman semusim dibandingkan dengan sistem perakaran pohon, mengakibatkan reduksi hasil tanaman semusim akibat kompetisi dengan pohon lebih besar (Nair, 1993).

\section{Jumlah dan Luas Daun Tanaman Sela}

Perlakuan pemangkasan dan pemupukan berpengaruh nyata terhadap pertumbuhan luas daun dan tidak berpengaruh terhadap jumlah daun, walaupun terdapat peningkatan kualitas pertumbuhan (Gambar 2). 


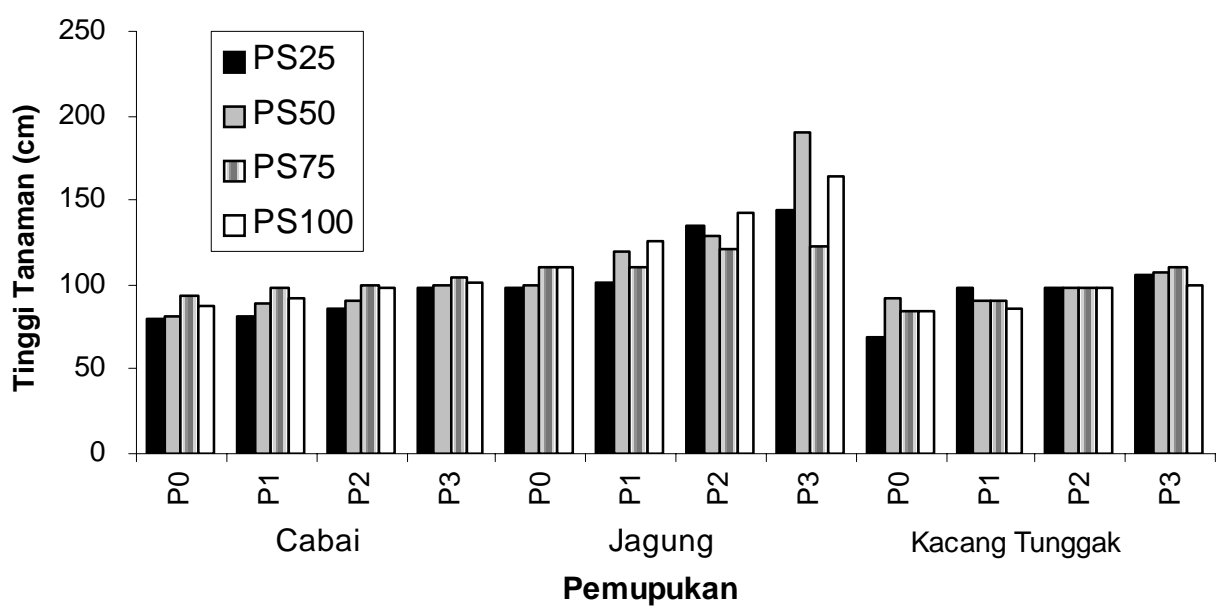

Gambar 1. Pengaruh pemangkasan tanaman sengon dan pemupukan terhadap pertumbuhan tinggi tanaman cabai, jagung dan kacang tunggak.

Dari ketiga jenis tanaman sela yang ditanam, ternyata tanaman jagung sangat tergantung dengan besar kecilnya intensitas pangkas yang dilakukan terhadap tanaman pokok sengon. Jumlah daun tanaman cabai lebih dipengaruhi oleh perlakuan pemupukan dibandingkan perlakuan pemangkasan tanaman (Gambar 2). Perlakuan PS 25 (P1, P2, P3) berturut-turut menghasilkan jumlah daun sebanyak 30, 34 dan 42 helai daun. Berbeda halnya dengan tanaman jagung, justru pada perlakuan pemupukan P3 (PS 50, PS 75, PS 100) terdapat perbedaan yang nyata, yaitu 9, 9 dan 10 helai daun. Hal ini menunjukkan bahwa pertumbuhan tanaman jagung dipengaruhi oleh intensitas cahaya yang masuk melalui teknik pemangkasan. Khusus tanaman kacang tunggak terlihat jelas bahwa pada PS 75 (P0, P1, P2 dan P3) berturut-turut memperoleh jumlah daun sebanyak 41, 49, 49 dan 54 helai daun. Hal ini berarti kacang tunggak tidak terlalu bermasalah terhadap kekurangan cahaya, tapi sebaliknya sangat respon terhadap pemupukan yang diberikan terutama pupuk NPK yang dikombinasikan dengan pupuk kandang.

Selama pertumbuhan awal tanaman sela, perlakuan pemangkasan dan pemupukan belum berpengaruh nyata terhadap variabel pertumbuhan tanaman. Hal ini diduga karena kebutuhan tanaman akan cahaya matahari, air tanah, dan unsur hara NPK masih relatif sedikit sehingga dapat tercukupi dan belum terjadi persaingan dengan tegakan sengon. Akan tetapi, dengan semakin meningkatnya umur tanaman, semakin meningkat pula ukuran tanaman sela sehingga makin banyak tanaman membutuhkan cahaya matahari, air tanah, dan unsur hara NPK.

Sejalan dengan pertumbuhan tanaman sela, mulai terjadi persaingan di antara individu tanaman sela dan di antara tanaman sela dengan tegakan sengon untuk memperebutkan cahaya matahari, air tanah, dan unsur hara 
NPK. Oleh karena itu pengaruh perlakuan pemangkasan dan pemupukan mulai signifikan sejalan dengan masa pertumbuhan tanaman sela dan akhirnya juga akan berpengaruh terhadap pertumbuhan tinggi, jumlah dan luas daun tanaman sela.
Pemupukan NPK pada tanaman vegetatif akan berpengaruh ganda terhadap tanaman, yaitu pengaruh langsung hara NPK dalam fisiologi tanaman dan pengaruh tidak langsung melalui modulasi dan fiksasi nitrogen secara simbiotik.

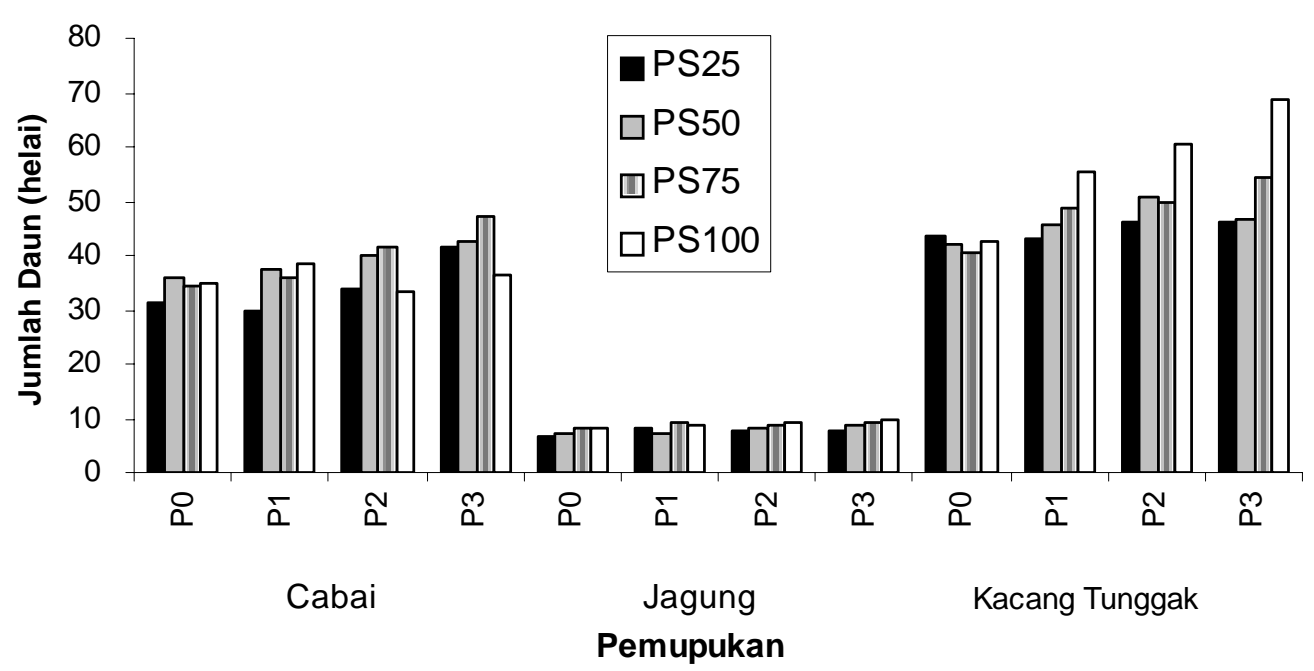

Gambar 2. Pengaruh pemangkasan tanaman sengon dan pemupukan terhadap jumlah daun tanaman cabai, jagung dan kacang tunggak.

Luas daun tanaman sela ketiga jenis tanaman sela sangat dipengaruhi oleh perlakuan pemupukan dan pemangkasan, semakin banyak sengon yang dipangkas semakin banyak pula cahaya yang masuk, maka daun pun semakin luas, misalnya PS25P0 dan PS100P3 akan memperoleh luas daun untuk tanaman cabai 129 dan $368 \mathrm{~cm}^{2}$, jagung 105.80 dan $295.40 \mathrm{~cm} 2$, dan kacang tunggak 472 dan $513.60 \mathrm{~cm} 2$ (Gambar 3).

Hasil penelitian ini menunjukkan bahwa naungan berpengaruh nyata terhadap pertumbuhan vegetatif. Naungan ringan (PS75) justru berpengaruh baik terhadap pertumbuhan vegetatif tanaman.
Namun demikian, naungan yang lebih berat dapat mereduksi pertumbuhan tanaman dan produksi biomasa dan hasil biji tanaman kacang tunggak. Pengaruh perlakuan pemangkasan tajuk sengon terhadap tanaman sela berkaitan erat dengan ketersediaan radiasi untuk fotosintesis dan kemungkinan juga ada kaitannya dengan ketersediaan air tanah dan kondisi temperatur udara mikro di lingkungan tajuk tanaman sela.

Secara biologis, produksi tanaman dapat dipandang sebagai suatu sistem konversi energi radiasi menjadi energi kimia yang dapat ditransportasikan dan disimpan. Konversi ini terjadi melalui reaksi-reaksi fotosintesis. Hasil penelitian ini menunjukkan, bahwa 
komponen pertumbuhan (tinggi tanaman, banyak daun pertanaman, luas daun per tanaman, dan berat kering bagian atas tanaman), komponen hasil (banyak bunga per tanaman, banyak polong per tanaman, banyak biji per tanaman, dan bobot biji), maupun hasil panen biji yang tinggi terjadi pada perlakuan pemangkasan $75 \%$ dan pemupukan NPK + pupuk kandang.

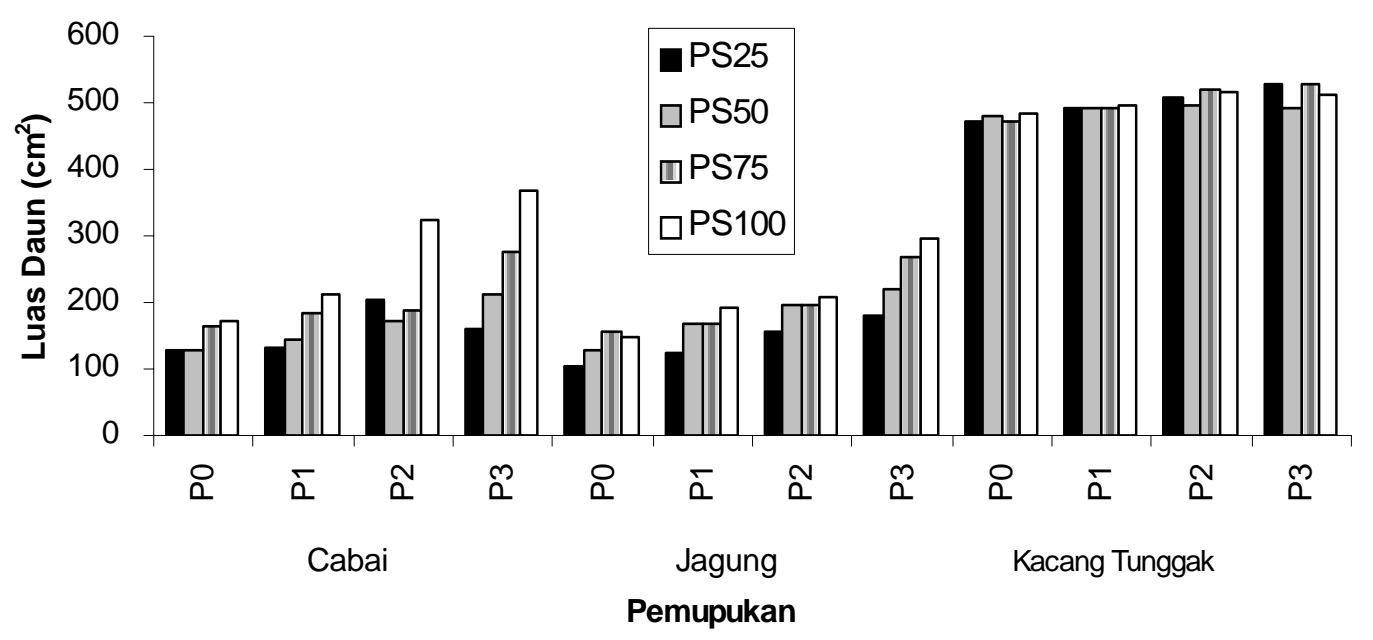

Gambar 3. Pengaruh pemangkasan tanaman sengon dan pemupukan terhadap luas daun tanaman cabai, jagung dan kacang tunggak.

\section{Berat Kering Tanaman Sela}

Perlakuan interaksi pemangkasan tajuk sengon dan pemupukan berpengaruh sangat nyata terhadap berat kering tanaman. Namun demikian, pengaruh perlakuan pemangkasan lebih besar dibandingkan dengan pengaruh pemupukan (Gambar 4). Hal ini menunjukkan bahwa produksi biomasa tanaman sela sangat peka terhadap naungan. Tanaman sela yang ditanam dengan perlakuan naungan berat tanpa pemupukan (PS25-P0) menghasilkan berat kering tanaman paling rendah dibandingkan dengan tanaman yang ditanam dengan perlakuan lainnya

Respon positif perlakuan pemupukan dapat dilihat pada perlakuan tanaman monokultur atau PS100 (P0, P1，P2，P3) berturut-turut berat kering tanaman cabai adalah 3.45 , 4.65, 3.91, $5.23 \mathrm{~g}$ tanaman-1, jagung adalah 4.18, 18.12, 15.76, $22.7 \mathrm{~g}$ tanaman-1 dan kacang tunggak adalah 14.24, 18.96, 16.08, $23.6 \mathrm{~g} /$ tanaman.

Tanaman sela yang ditanam secara monokultur (P100) menghasilkan berat kering yang paling tinggi. Khusus untuk tanaman jagung, secara umum dapat dikatakan bahwa pertumbuhan tanaman jagung sangat dipengaruhi oleh besarnya intensitas cahaya matahari. Tanaman jagung yang ditanam di antara tanaman sengon yang tidak dipangkas atau hanya dipangkas $25 \%$ pertumbuhannya sangat terhambat. 


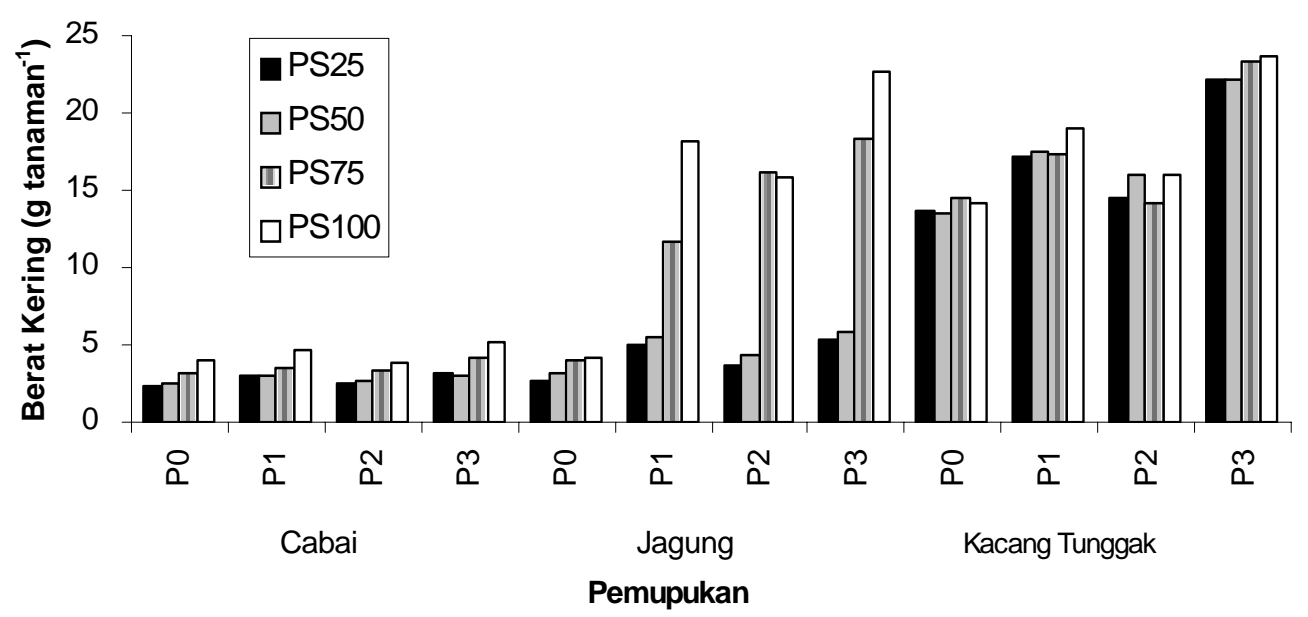

Gambar 4. Pengaruh pemangkasan tanaman sengon dan pemupukan terhadap berat kering tanaman cabai, jagung dan kacang tunggak.

\section{Berat Panen Tanaman Sela}

Produksi tanaman sela cabai, jagung, dan kacang tunggak akan semakin tinggi hasilnya dengan peningkatan intensitas pemangkasan sengon (Gambar 5). Demikian juga respon tanaman terhadap pemupukan. Kombinasi pemupukan N, P, K dan pupuk kandang justru memperoleh hasil yang paling tinggi bila dibandingkan perlakuan lainnya.

Tanaman kacang tunggak misalnya, dengan kombinasi perlakuan P25 (P0, P1, P2, P3) masih menunjukkan hasil yang cukup baik, yaitu sebesar 1902, 2074, 2476 dan $2414 \mathrm{~kg} /$ ha meskipun menunjukkan hasil yang lebih rendah dan berbeda nyata bila dibandingkan dengan kacang tunggak yang ditanam secara monokultur PS 100 (P0, P1, P2, P3) sebesar 2007, 2358. 2804, dan 3152 $\mathrm{kg} / \mathrm{ha}$ (Gambar 5) Hal ini membuktikan bahwa tanaman kacang tunggak mampu tumbuh dan berproduksi dengan baik bila ditanam di bawah tegakan sengon umur dua tahun lebih, dan tidak terlalu bermasalah pertumbuhannya walaupun ternaungi oleh tanaman pokok.

Pada penelitian ini perlakuan interaksi pemangkasan tajuk sengon dan pemupukan berpengaruh sangat nyata terhadap hasil panen tanaman sela cabai, jagung, dan kacang tunggak. Efek rendahnya intensitas radiasi sebagai akibat dari perlakuan pemangkasan berpengaruh lebih besar terhadap pertumbuhan dan hasil tanaman sela. Pengaruh terhadap produksi jagung sangat serius, bahkan sebagian perlakuan pemangkasan mengakibatkan tanaman jagung tidak berhasil memproduksi tongkol dan biji yang baik.

Pengaruh perlakuan pemangkasan tajuk sengon terhadap pertumbuhan dan produksi tanaman sela berkaitan erat dengan ketersediaan radiasi untuk fotosintesis daun tanaman cabai dan jagung (tanaman C4). Produksi tanaman dapat dipandang sebagai suatu sistem konversi energi radiasi menjadi energi kimia melalui reaksi-reaksi fotosintesis. Hasil analisis ragam menunjukkan bahwa perlakuan pemangkasan dan 
kombinasi pupuk organik dan anorganik berpengaruh nyata terhadap tinggi tanaman, jumlah daun, luas daun, berat kering tanaman, jumlah bunga, jumlah buah, dan berat panen.

Data yang disajikan pada Gambar 5 menunjukkan bahwa produksi tanaman sela sangat membutuhkan cahaya untuk kelangsungan hidupnya, bahkan pada daerah dekat tumbuhan yang tidak dipangkas namun tetap ditanam, hasilnya menunjukkan pertumbuhan yang kurang bagus, bahkan ada yang tidak tumbuh sama sekali. Hal tersebut sejalan dengan pendapat Huxley (1985) bahwa pertumbuhan tanaman pada keadaan kekurangan cahaya akan mengganggu proses fotosintesis sehingga terjadi pengurangan ukuran, kualitas tanaman terutama energi rendah sebagai akibatnya pertumbuhan vegetatif yang terganggu terutama pada jenis-jenis tanaman yang tidak tahan ternaungi (golongan C4) dan kondisi ini jelas akan berpengaruh terhadap produksi tanaman. Oleh karena itu semakin banyak pemangkasan sengon dilakukan, maka hasil panen semakin tinggi.

Pada sengon yang dipangkas $75 \%$ (PS 75), diberi kombinasi pupuk NPK + pupuk kandang hasil tanaman sela cabai, jagung, dan kacang tunggak yang paling tinggi yaitu $1.801 \mathrm{~kg} / \mathrm{ha} ; 1.774$ $\mathrm{kg} / \mathrm{ha}$; dan $3.476 \mathrm{~kg} / \mathrm{ha}$, meskipun hasilnya lebih rendah bila dibandingkan dengan tanaman sela monokultur yaitu $33.55 \mathrm{~kg} / \mathrm{ha} ; 25.48 \mathrm{~kg} / \mathrm{ha}$; dan 31.52 $\mathrm{kg} / \mathrm{ha}$. Pemangkasan sengon $75 \%$ tersebut tidak berpengaruh nyata antara sengon yang dipangkas dan sengon yang tidak dipangkas terhadap volume kayu, bahkan terdapat perbaikan kualitas pertumbuhan tanaman, dimana sengon monokultur sebanyak $21.36 \mathrm{~m} 3 /$ ha dan sengon agroforestri sebanyak $22.71 \mathrm{~m} 3$ /ha (Tabel 2).
Data yang disajikan pada Tabel 2 tersebut menjelaskan bahwa sistem agroforestri tanaman sela cabai, jagung, dan kacang tunggak tidak mengganggu pertumbuhan tanaman pokok bahkan dapat memacu pertumbuhan, karena diduga mendapat suplai hara dari perlakuan pemupukan. Kontribusi Nitrogen dari tegakan sengon merupakan sumber nitrogen yang sangat penting bagi tanaman sela dalam sistem agroforestri dan kontribusi nitrogen ini sangat beragam tergantung dengan biomassa tanaman pokok yang ditanam.

Naungan pohon sengon menyebabkan efek neto dari proses interaksi antar komponen system berupa reduksi panas dan cahaya, suhu, kelembaban, dan pergerakan udara yang akan berpengaruh terhadap fotosintesis, transpirasi dan keseimbangan energi pada tanaman sela dan pada akhirnya akan berpengaruh terhadap hasil tanaman (Rosenberg et al., 1983).

Data yang disajikan pada Gambar 5 menjelaskan bahwa rata-rata Harvest Equivalent Level Petani (HELP) yang ditanam di bawah tegakan sengon umur maksimum 1.5 tahun menghasilkan berat panen cabai, jagung, dan kacang tunggak sebesar $1.205 \mathrm{~kg} / \mathrm{ha} ; 1.050 \mathrm{~kg}$ /ha dan $1.608 \mathrm{~kg} \mathrm{/ha,} \mathrm{dan} \mathrm{ini}$ merupakan kesempatan akhir dalam kontrak kerja pesanggem dengan Perhutani.

Selanjutnya hasil penelitian menunjukkan tanaman tanpa pupuk menyebabkan terjadinya pengurangan pada warna, ukuran dan kualitas tanaman, yang disertai pula dengan pengurangan pada hasil, bahkan kanopi daun, tanaman tumbuh kerdil dan sistem perakarannya terbatas. Ukuran daun lebih kecill demikian juga dengan ukuran hasil yang merupakan bentuk dari akumulasi karbohidrat (Locasscio et 
al., 1985), tetapi sebaliknya, yang selalu berlebihan akan menghasilkan pemanjangan pucuk, jaringan tanaman menjadi sukulen dan daun berwarna gelap tidak normal. Selain itu juga dapat memperlambat pemasakan buah (Janick, 1974).
Pemupukan sangat penting bagi produksi tanaman sela terutama produksi buah dan persentase fruitset meningkat pada pemupukan organik dosis tinggi (Maynard et al., 1981).

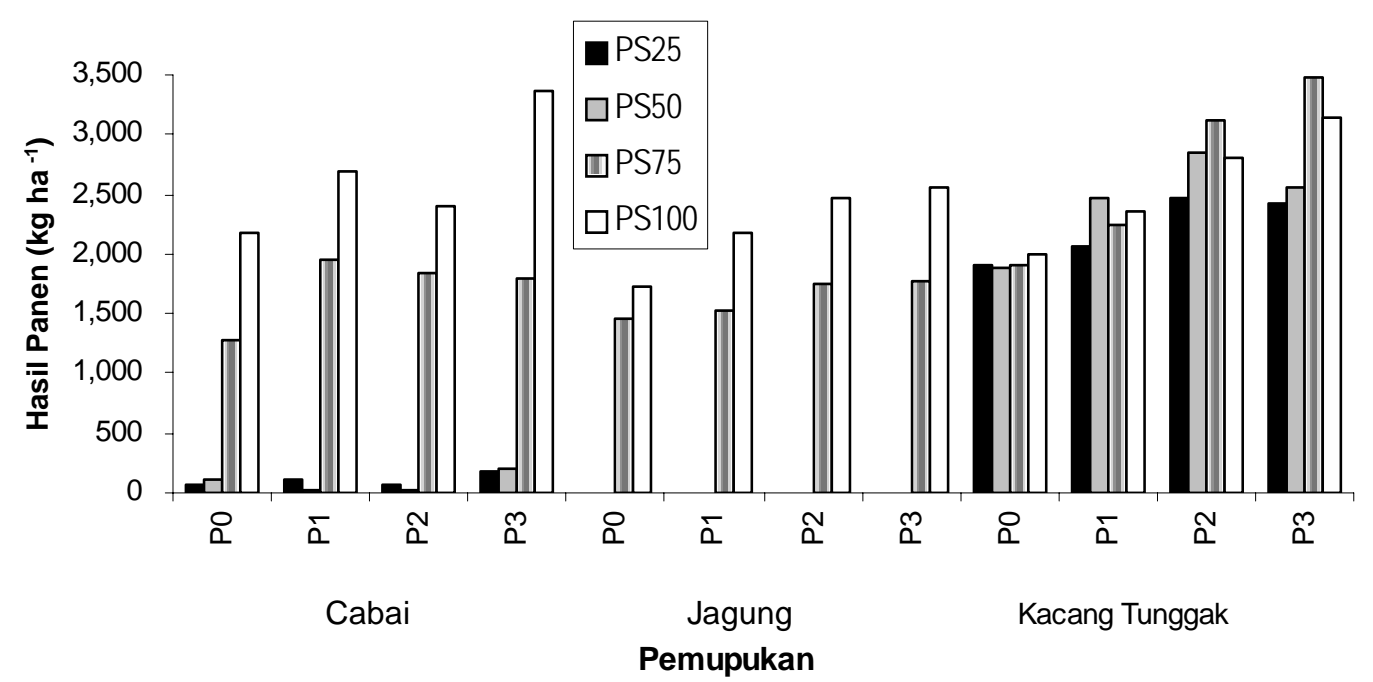

Gambar 5. Pengaruh pemangkasan tanaman sengon dan pemupukan terhadap hasil panen tanaman cabai, jagung dan kacang tunggak.

Kacang tunggak yang ditanam (tanpa pupuk) pada berbagai tingkat pemangkasan tidak menunjukkan perbedaan yang nyata, misalnya pada perlakuan P0 (PS25, PS50, PS75, PS100) memperoleh hasil sebanyak 1902, 1893, 1914, dan $2007 \mathrm{~kg} / \mathrm{ha}$ (Gambar 5), artinya pada tingkat pemangkasan yang berbeda tanaman tersebut masih bisa berproduksi dan tidak berpengaruh terhadap perlakuan pemangkasan. Hal ini dapat dikatakan bahwa tanaman tersebut toleran terhadap naungan dalam sistem agroforestri umur dua tahun, bahkan pada tanaman lanjutan dimana sengon umur 3 tahun tanaman kacang tunggak masih berproduksi dengan baik.
Jadi pada penelitian ini justru yang berpengaruh adalah perlakuan pemupukan, misalnya tanaman kacang tunggak yang ditanam tanpa naungan sengon (PS 100) justru perlakuan pemupukan P0, P1, P2, P3 menunjukkan hasil berturur-turut adalah 2.007, 2.358, 2.804, dan $3.152 \mathrm{~kg} / \mathrm{ha}$. Angka ini menunjukkan bahwa kombinasi pupuk N, P, K dan pupuk kandang justru memberikan hasil yang paling tinggi dibandingkan dengan perlakuan pemupukan lainnya.

Berbeda dengan kacang tunggak, tanaman cabai justru pada tingkat pemangkasan $25 \%$ dan $50 \%$ produksi cabai sangat rendah misalnya pada perlakuan PS 25 (P0, P1, P2, P3) hanya mencapai 62, 104, 73, dan $178 \mathrm{~kg} / \mathrm{ha}$. 
Perlakuan PS 50 pun demikian, yaitu hanya 106, 12, 21, dan $192 \mathrm{~kg} / \mathrm{ha}$ (Gambar 5). Perlakuan pemangkasan maupun pemupukan tidak menunjukkan pengaruh yang nyata terhadap produksi cabai.

Pengaruh perlakuan mulai terlihat berbeda setelah dilakukan pemangkasan tanaman pokok sengon sebesar $75 \%$ (PS 75), cahaya semakin banyak masuk dan hasilpun semakin meningkat, misalnya perlakuan pupuk $\mathrm{N}, \mathrm{P}, \mathrm{K}$ dan pupuk kandang pada tingkat pemangkasan $25 \%, \quad 50 \%$, dan $75 \%$ berturut-turut hasil cabai adalah 178, 1.92 dan $18.01 \mathrm{~kg} / \mathrm{ha}$, bahkan hasil tertinggi diperoleh pada tanaman cabai tanpa naungan (PS 100) yaitu mencapai $33.55 \mathrm{~kg} / \mathrm{ha}$. Angka- angka tersebut di atas menunjukkan bahwa tanaman cabai dalam mempertahankan pertumbuhannya sangat tergantung dengan intensitas cahaya yang masuk.

Tanaman cabai masih bisa diusahakan di bawah tegakan tapi perlu diikuti teknologi pemangkasan yang sesuai. Cabai bisa diusahakan dalam Sistem agroforestri sengon tetapi harus diikuti oleh perlakuan pemangkasan minimal $75 \%$.

Dari tiga jenis tanaman yang ditanam dalam ssstem agroforestri sengon umur dua tahun, ternyata tanaman jagung tidak bisa menghasilkan sama sekali jika dilakukan pada tegakan sengon yang dipangkas $25 \%$ dan $50 \%$ kacang tunggak tidak terpengaruh, cabai masih bisa berhasil meskipun hasilnya sangat rendah, sedangkan jagung hanya bisa dipanen hijauan makanan ternak saja. Namun demikian halnya dengan tanaman jagung masih mampu berproduksi di bawah tegakan sengon dengan pemangkasan minimal $75 \%$.

Kombinasi perlakuan PS 75 (P0, P1, P2, P3) produksi jagung berturutturut adalah $1.462,1.521,1.742$ dan
$1.774 \mathrm{~kg} / \mathrm{ha}$ dan berbeda nyata dengan jagung yang ditanam secara monokultur PS 100 (P0, P1, P2, P3) berturut - turut hasilnya adalah 1.727, 2.178, 2.479 dan $2.548 \mathrm{~kg} / \mathrm{ha}$. Hasil yang paling tinggi pada kombinasi perlakuan pupuk N, P, $\mathrm{K}$ dan pupuk kandang yang ditanam tanpa naungan yaitu sebesar $2.548 \mathrm{~kg}$ /ha.

Sama halnya tanaman cabai, jagung membutuhkan sinar matahari yang cukup dalam pertumbuhannya agar berproduksi dengan baik. Secara umum dapat dikatakan di antara ketiga jenis tanaman sela yang ditanam di bawah tegakan sengon umur dua tahun, justru tanaman

Kacang tunggak yang paling toleran terhadap pertumbuhan dan hasilnya. Oleh karena itu dalam penelitian ini sengaja dilakukan penanaman lanjutan tanaman kacang tunggak sampai sengon berumur 3 tahun dan ternyata hasilnya masih tetap bisa diandalkan. Peningkatan buah panen berkaitan erat dengan peningkatan jumlah cabang cabai, dimana kuncup bunga muncul pada cabang tanaman. Kuncup bunga muncul bersamaan dengan terbentuknya cabang. Dengan demikian dapat dijelaskan bahwa suplai pupuk dapat merangsang pertumbuhan daun dan cabang, yang secara tidak langsung juga merangsang terbentuknya kuncup bunga.

Pemberian pupuk anorganik yang berlebihan akan menyebabkan pertumbuhan vagetatif tanaman menjadi lebih dominan. Namun sebaliknya, suplai $\mathrm{N}$ dalam jumlah yang cukup, yang ditunjang dengan kesempatan yang maksimum untuk memproduksi karbohidrat, membuat pertumbuhan vegetatif tidak berlebihan dan hasil buah meningkat. Pertumbuhan akan dipertahankan dalam keseimbangan yang baik diantara 
proses vegetatif dan reproduktif sehingga mencapai hasil yang maksimum.

Berdasarkan uraian di atas dapat dijelaskan bahwa hasil ditentukan oleh tingkat pertumbuhan organ - organ vegetatif tanaman. Pertumbuhan dan perkembangan tanaman dicirikan dengan meningkatnya bahan kering. Akumulasi bahan kering terjadi jika daun yang merupakan organ fotosintesis mampu berperan sebagai pengekspor fotosintat ke organ lain, dan ini merupakan sumbangan yang positif terhadap laju produktivitas tanaman. Hal ini tidak terlepas dari pertumbuhan dan perkembangan daun.

Pertumbuhan dan perkembangan organ-organ vegetatif tanaman dipengaruhi oleh intensitas cahaya. Meningkatnya pertumbuhan dan perkembangan tanaman akan diikuti dengan meningkatnya akumulasi bahan kering. Pada awal pertumbuhan tanaman, partisi bahan kering ke daun mengalami peningkatan.

Setelah tanaman mencapai fase generatif, partisi bahan kering ke daun lambat laun mengalami penurunan. Pada fase generatif ini terjadi proses penuaan dari daun, akar dan batang, serta merupakan fase perkembangan bunga, buah dan biji, dan persentase bahan kering terbesar dialokasikan ke organ-organ generatif (bunga dan buah). Semua proses ini bisa berjalan sempurna jika ketersediaan cahaya cukup untuk kelangsungan proses fotosintesis.

Periode anthesis dalam tanaman cabai relatif singkat. Sinkronisasi taraf pemasakan antara androcium dan gynecium tidak sempurna, pada fase pertunasan stigma siap menerima pollen, tetapi pollennya sendiri seringkali belum masak (Monselise, 1986). Kebanyakan bunga cabai membuka selama periode dua jam pertama setelah matahari terbit. Setelah batal membuka sempurna, segera diikuti oleh periode bunga layu. Menurut Monselise (1986), anthera menjadi layu pada waktu yang berbeda-beda selama siang hari, dan suhu udara tampaknya menjadi faktor yang sangat menentukan.

\section{Kesimpulan}

Pemangkasan tanaman sengon dan penanaman tanaman sela di antara tanaman sengon ternyata tidak menghambat pertumbuhan tanaman sengon, justru memacu pertumbuhan tanaman sengon. Pemangkasan sengon $75 \%$ menghasilkan pertambahan tinggi, diameter dan volume kayu lebih besar dibandingkan dengan pemangkasan $50 \%$, dan $25 \%$. Pengaruh positif sangat nyata dijumpai pada perlakuan pemangkasan sengon $75 \%$.

Pemangkasan tanaman sengon berpengaruh nyata terhadap pertumbuhan tanaman sela cabai, jagung dan kacang tunggak. Semakin banyak bagian tanaman sengon yang dipangkas maka pertumbuhan tanaman sela cabai, jagung, dan kacang tunggak semakin baik. Produksi tanaman sela cabai, jagung, dan kacang tunggak akan semakin tinggi hasilnya dengan peningkatan intensitas pemangkasan sengon. Demikian juga respon tanaman terhadap pemupukan..

\section{Daftar Pustaka}

Cannell, J.H. 1983. Plant management in agroforestri: manipulation of trees, population densities and mixtures of trees and herbaceous crops. Plant Research and Agroforestri (Huxley, P.A. eds) ICRAF, Nairobi, Kenya.

Huxley, P.A. 1985. The tree/crop interface - or simplifying the biological /environmental study of mixed 
cropping agroforestri systems. Agroforestri Systems 3:251-266.

Janick, J. 1974. Horticultural Science. W.H.

Freeman and Company. New York. 746 pp.

Locasscio, S.J., J.G.A. Fiskel, and D.A. Graetz. 1985. Nitrogen accumulation by pepper as influenced by mulch and time of fertilizer application. J. Amer. Soc. Hort. Sci. 110(3):325-328.

Maynard,L.N., R.M.Lachman, M.R.Check, dan H.F.Vernell. 1981. The influence of nitrogen on flowering and fruitset of peppers. Proc. Am. Soc. Hortic. Sci. 81: 385-389.
Monselise, S.P. 1986. Handbook of Fruit Set and Development. CRC Press, Inc. Boca Raton, Florida.

Nair, P.K.R. 1993. An Introduction to Agroforestri. Kluwer Academic Publisher, London, in Cooperation with International Center for Reasearch in Agroforestri, ICRAF, Nairobi, Kenya.

Rosenberg, N.J., B.L.Blad, dan D.B. Verma. 1983. Microclimate: The Biological Environment. 3 rd ed. Wiley and Sons, New York, USA.

Young, A. 1989. Agroforestri for Soil Conservation. ICRAF, Nairobi and CAB International, Wallingford, UK. 